\title{
Evaluation of Culture Medium for the Growth of Alternaria brassicae causing Alternaria Blight of Mustard
}

\author{
Bhagyashree Singh*, R.K. Pandya, Ravi Yadav, Ajay Kaurav and Prashant K. Singh
}

R. V. S. K. V. V. College of Agriculture Gwalior (M.P.), India

*Corresponding author

\begin{tabular}{|c|c|}
\hline & A B S T R A C T \\
\hline & \multirow{6}{*}{$\begin{array}{l}\text { Rapeseed-mustard (Brassica juncea } \mathrm{L} \text { ) is an economically prodigious and utile oilseed } \\
\text { crop of the world. Potato dextrose agar media was significantly superior over other tested } \\
\text { media at } 5 \text { and } 7 \text { days after inoculation. However it was at par with mustard leaf dextrose } \\
\text { agar at } 3 \text { days after inoculation and significantly superior over the rest culture media. The } \\
\text { maximum mycelia growth on seven days after inoculation was recorded in Potato dextrose } \\
\text { agar medium }(90.00 \mathrm{~mm}) \text { followed by Mustard leaf dextrose agar }(70.00 \mathrm{~mm}) \text {, Potato leaf } \\
\text { dextrose agar medium }(68.33 \mathrm{~mm}) \text {, Cauliflower dextrose agar medium }(60.16 \mathrm{~mm}) \text {, } \\
\text { Czapex dextrose agar medium }(60.00 \mathrm{~mm}) \text {, Malt dextrose agar medium }(58.33 \mathrm{~mm}) \text {, } \\
\text { Tomato leaf dextrose agar media }(51.66 \mathrm{~mm}) \text {, Marigold leaf dextrose agar medium } \\
(50.16), \text { Pea grain dextrose agar medium }(48.33 \mathrm{~mm}) \text {, Cauliflower dextrose agar medium } \\
(43.66 \mathrm{~mm}) \text {, Malt apple dextrose agar medium }(43.33 \mathrm{~mm}) \text {, Radish potato dextrose agar } \\
\text { medium }(40.00 \mathrm{~mm}) \text {, water agar medium }(36.83 \mathrm{~mm}) \text { and Carrot potato dextrose agar } \\
\text { medium }(28.33) \text {. While minimum growth was recorded in Pea husk dextrose agar medium } \\
(20.36 \mathrm{~mm}) \text {. }\end{array}$} \\
\hline & \\
\hline & \\
\hline Article Info & \\
\hline $\begin{array}{l}\text { Accepted: } \\
\text { 04 September } 2017 \\
\text { Available Online: } \\
\text { 10 November } 2017\end{array}$ & \\
\hline & \\
\hline
\end{tabular}

\section{Introduction}

Rapeseed-mustard (Brassica juncea L) is an economically prodigious and utile oilseed crop of the world. In India, rapeseed-mustard is grown over in diverse agro-climatic conditions ranging from north-eastern/northwestern hills to down south. It is second largest indigenous oilseed crop, contributing 32 per cent of total oilseed production in India.Forty two fungal pathogens are associated with rapseed mustard out of these Alternaria blight caused by Alternaria brassicae (Berk) Sacc. And Alternaria brassicicola (Schw.) Wiltsh, are the most important diseases causing heavy losses throughout the country attacking all brassica species. Four species of Alternaria viz.,
Alternaria brassicae (Berk) Sacc. Alternaria brassicicola (Schw.) Wiltsh. Alternaria raphani Groves and Skolka and A. alternata (Fr) Keissler have been reported for the cause of Alternaria blight. This pathogen is characterized as pseudo-fungi with absence of identifiable sexual stage and reported as cosmopolitan in nature. The causal pathogen is characterized by large obclavate, olive grey to dark coloured conidia having longitudinal as well as transverse septa (Aneja and Agnihotri, 2013).A critical and comprehensive knowledge of nutritional patterns and factor influencing the growth of fungi is prerequisite for any study leading to the understanding of host -pathogen 
relationship. Hence tested the different culture medium for the mycelia growth as well as colony characteristics of the A. brassicae.

\section{Materials and Methods}

The different solid mediums were evaluated for obtaining maximum mycelial growth of the Alternaria brassicae. The experiment was laid out in complete randomized design with replicated three times. Ten solid culture medias viz., Malt Extract Apple Agar medium, Malt Extract Agar medium, Czapek's-Dox Agar medium, Potato Dextrose Agar medium, Potato Carrot Agar medium, Mustard leaf Dextrose Agar medium, Pea leaves Dextrose Agar medium, Pea husk Dextrose Agar medium, Pea grain Dextrose Agar medium, Cauliflower leaf Potato Dextrose Agar, Cauliflower Dextrose Agar, Raddish Dextrose Agar and Water Agar were used to compare the growth rate of Alternaria brassicae. The Culture Mediums were prepared by the standardized method and autoclaved at $121.6{ }^{\circ} \mathrm{C}, 15 \mathrm{psi}$ pressure for twenty minutes. Uniform quantities $(20 \mathrm{ml})$ of each medium were poured in $90 \mathrm{~mm}$ Petri plates. Each Petri plate was inoculated separately with uniform mycelia culture bits $(5 \mathrm{~mm})$ cut with the help of cork borer from young (5 days) vigorously growing culture were placed on the middle of the each pre poured medium and incubated at $25 \pm 1$ oC.Each treatment was replicated three times. The diameter of the growth of the fungus was measured after inoculation 3, 5, and 7 days on radial growth of mycelium.

\section{Results and Discussion}

\section{Radial growth of the pathogen}

In order to find out the most effective culture media for the growth of A. brassicae. A total fifteen culture media were evaluated against A. brassicae under in vitro condition and the data summarized in table 1 no- reveals that Potato dextrose agar media was significantly superior over other tested media at 5 and 7 days after inoculation. However it was at par with mustard leaf dextrose agar at 3 days after inoculation and significantly superior over the rest culture media.

The maximum mycelia growth on seven days after inoculation was recorded in Potato dextrose agar medium $(90.00 \mathrm{~mm})$ followed by Mustard leaf dextrose agar $(70.00 \mathrm{~mm})$, Potato leaf dextrose agar medium (68.33 $\mathrm{mm})$, Cauliflower dextrose agar medium (60.16 mm), Czapex dextrose agar medium $(60.00 \mathrm{~mm})$, Malt dextrose agar medium $(58.33 \mathrm{~mm})$, Tomato leaf dextrose agar media $(51.66 \mathrm{~mm})$, Marigold leaf dextrose agar medium (50.16),Pea grain dextrose agar medium (48.33 mm), Cauliflower dextrose agar medium (43.66 mm), Malt apple dextrose agar medium (43.33 mm), Radish potato dextrose agar medium $(40.00 \mathrm{~mm})$, water agar medium $(36.83 \mathrm{~mm})$ and Carrot potato dextrose agar medium (28.33). While minimum growth was recorded in Pea husk dextrose agar medium $(20.36 \mathrm{~mm})$.

\section{Colour of the culture}

Among all media tested for evaluation, colour of culture did not differ from each other.

A total fifteen culture media were evaluated against $A$. brassicae under in vitro condition. The maximum mycelia growth was found in Potato dextrose agar media followed by Mustard leaf dextrose agar medium and potato leaf dextrose agar medium. While the least mycelia growth was recorded in Pea husk dextrose agar medium. Similarly he founded that maximum growth of the pathogen was recorded in Mustard leaf agar medium followed by Nutrient agar, CzapekDox-agar and Potato-Dextrose-agar and minimum growth was recorded on Malt agar. 
Mustard Leaf Agar medium was found more appropriate for the culture of A. blight as it was significantly superior over three tested media (Shakya 2012).

Table.1 Evaluation of different culture medium against A. brassicae

\begin{tabular}{|l|l|l|l|l|l|}
\hline S.No & Solid culture medium & \multicolumn{3}{|c|}{ Mycelial growth(mm) } & Culture colour \\
\cline { 2 - 4 } & $\begin{array}{l}\text { Pea husk dextrose agar } \\
\text { medium }\end{array}$ & 6.83 & 16.66 & 20.36 & $\begin{array}{l}\text { Light brown } \\
\text { colour whitish } \\
\text { cottony growth }\end{array}$ \\
\hline 2 & $\begin{array}{l}\text { Cabbage dextrose agar } \\
\text { medium }\end{array}$ & 11.66 & 28.33 & 43.66 & Light brown \\
\hline 3 & $\begin{array}{l}\text { Cauliflower potato dextrose } \\
\text { agar medium }\end{array}$ & 18.33 & 43.33 & 60.16 & Dark black colour \\
\hline 4 & $\begin{array}{l}\text { Pea grain dextrose agar } \\
\text { medium }\end{array}$ & 21.66 & 33.33 & 48.33 & Light brown \\
\hline 5 & $\begin{array}{l}\text { Carrot potato dextrose agar } \\
\text { medium }\end{array}$ & 10.00 & 13.33 & 28.33 & Dark brown \\
\hline 6 & $\begin{array}{l}\text { Marigold leaf dextrose agar } \\
\text { medium }\end{array}$ & 15.00 & 31.66 & 50.16 & Dark brown \\
\hline 7 & Malt Apple dextrose agar & 16.66 & 30.66 & 43.33 & Black \\
\hline 8 & $\begin{array}{l}\text { Mustard leaf dextrose agar } \\
\text { medium }\end{array}$ & 38.333 & 53.33 & 70.00 & Black \\
\hline 9 & $\begin{array}{l}\text { Raddish potato dextrose agar } \\
\text { medium }\end{array}$ & 21.00 & 30.00 & 40.00 & Light brown \\
\hline 10 & Malt dextrose agar medium & 30.00 & 32.66 & 58.83 & Light brown \\
\hline 11 & Czapex dextrose medium & 18.33 & 30.00 & 60.00 & Light black \\
\hline 12 & Water agar medium & 14.00 & 31.00 & 36.83 & Black \\
\hline 13 & $\begin{array}{l}\text { Potato dextrose agar } \\
\text { medium }\end{array}$ & 36.66 & 63.33 & 90.00 & Black \\
\hline 14 & $\begin{array}{l}\text { Potato leaf dextrose agar } \\
\text { medium }\end{array}$ & 26.66 & 52.33 & 68.33 & Dark Brown \\
\hline 15 & $\begin{array}{l}\text { Tomato leaf dextrose agar } \\
\text { medium }\end{array}$ & 23.33 & 38.33 & 51.66 & Dark Brown \\
\hline
\end{tabular}

\begin{tabular}{|c|c|c|c|}
\hline Sem \pm & 1.55 & 1.68 & 1.54 \\
\hline CD at 5\% & 4.50 & 4.87 & 4.47 \\
\hline
\end{tabular}

Earlier Ansari et al., (1988) found that Alternaria brassicae growth sporulates well on range of media but maximum growth was recorded in PDA.Mehta and Sangwan (1998) found that mustard leaf extract media was compared favorably with other 12 other culture medium for the growth and sporulation of $A$. brassicae.

\section{References}

Aneja, J.K., Agarwal, A. and Agnihotri, A. 2013. Inter and intra-specific diversity in Alternaria species infecting oilseed Brassicas in India. Journal of Oilseed Brassica, 5 (2): 102-117.

Ansari, N.A., Khan, M.W. and Muheet, A. 
1988. Identify and cultural characters of the pathogen causing Alternaria blight of rapeseed and mustard. J. Oilseeds Res. 5: 33-39.

Mehta, N., Sangwan, M.S. and Srivastava, M.
P. 2003. Morphological and Pathological variations in rapeseed and mustard isolates of Alternaria brassicae. Ind Phytopathol 56(2): 188190

\section{How to cite this article:}

Bhagyashree Singh, R.K. Pandya, Ravi Yadav, Ajay Kaurav and Prashant K. Singh. 2017. Evaluation of Culture Medium for the Growth of Alternaria brassicae causing Alternaria Blight of Mustard. Int.J.Curr.Microbiol.App.Sci. 6(11): 325-328.

doi: https://doi.org/10.20546/ijcmas.2017.611.036 